\title{
LIPID CONTENT, MITOCHONDRIAL ACTIVITY AND EARLY EMBRYO DEVELOPMENT IN OOCYTE COLLECTED FROM CROSSBRED COWS (Bos taurus indicus)
}

\author{
Yoeli Mendez ${ }^{1}$ \\ Nohely Parra ${ }^{2}$ \\ Francisco Baez ${ }^{2}$ \\ Robert Valeris ${ }^{3}$ \\ Patricia Villamediana ${ }^{2}$
}

\begin{abstract}
The objective of this research was to evaluate the effect of phenotypic predominance on lipid content, mitochondrial activity and early developmental competence as indicators of oocyte quality. Cumulus-oocyte complexes (COCs) were recovered through follicular aspiration, and underwent in vitro maturation (IVM), in vitro fertilization (IVF), and in vitro culture (IVC) of presumptive zygotes. Lipid content and mitochondrial activity in immature and IVM oocytes were determined. A maturation rate of $80.6 \%$ and $69.3 \%$ was found for oocytes predominantly $B$. indicus and predominantly $B$. taurus, respectively. Total fertilization rate was $27.6 \% ; 26.1 \%$ for predominantly $B$. indicus oocytes and $29 \%$ for predominantly $B$. taurus oocytes. A total of $55.5 \%$ and $57.5 \%$ of cleaved embryos after 48 and $72 \mathrm{~h}$ post-insemination (hpi) in predominantly $B$. indicus group were observed, respectively. As for the predominantly B. taurus group, $48.6 \%$ and $60.4 \%$ of cleaved embryos were found after 48 and $72 \mathrm{hpi}$, respectively. In both groups, immature oocytes showed a greater amount of small lipidic droplets ( $\mathrm{p}<0.0001)$; IVM decreased the number of small lipid droplets $(\mathrm{p}<0.0001)$ and increased the number of medium and large lipid droplets $(\mathrm{p}<0.0001)$. Predominantly $B$. indicus oocytes had a greater number of small and medium-sized lipid droplets, while there were no significant differences in large lipid droplets. IVM oocytes had higher mitochondrial activity than immature oocytes group $(\mathrm{p}<0.05)$ without any effect of phenotypic predominance on this parameter. Assessment of lipid content was not a predictive factor of oocyte quality in crossbred cows.
\end{abstract}

Key words: Oocyte quality, lipid content, phenotypic predominance, Bos indicus, Bos taurus.

\section{CONTEÚDO LIPÍDICO, ATIVIDADE MITOCONDRIAL E DESENVOLVIMIENTO EMBRIONÁRIO PRECOCE DE OÓCITOS COLETADOS DE VACAS MESTIÇAS (Bos taurus indicus)}

\section{RESUMO}

O objetivo deste trabalho foi avaliar o efeito da predominância fenotípica no conteúdo lipídico como um indicador da qualidade do oócito. Os COC foram recuperados por aspiração folicular e submetidos a maturação in vitro (IVM), fertilização in vitro (FIV) e cultura in vitro (CIV). Determinou-se o conteúdo lipídico e atividade mitocondrial em oócitos imaturos e IVM. A taxa de maturação total era de $75 \%$, com valores de $80,6 \%$ e $69,3 \%$ para oócitos predominantemente $B$. Indicus e predominantemente $B$. taurus, respectivamente. A taxa de fertilização total foi de 27,6\%, para oócitos predominantemente $B$. indicus e

\footnotetext{
${ }^{1}$ Técnico de Área Inversiones Porcinas Venezuela. Correspondência.

${ }^{2}$ Laboratorio de Citogenética, Departamento de Biología, Facultad Experimental de Ciencias. Universidad del Zulia.

${ }^{3}$ Universidad del Zulia, Facultad de Ciencias Veterinarias.
}

Mendez Y, Parra N, Baez F, Valeis R, Villamediana P. Lipid content, mitochondrial activity and early embryo development in oocyte collected from crossbred cows (Bos taurus indicus). Vet. e Zootec. 2018 mar.; 25(1): 120-131. 
predominantemente $B$. taurus, este foi de $26,1 \%$ e $29 \%$, respectivamente. Um total de $52,1 \%$ de embriões divididos e 58,9\% foi observada após 48 e 72 horas após a inseminação (hpi), respectivamente. Além disso, para o grupo predominantemente B. indicus 55,5\% e 57,5\% embrião clivada após 48 e 72 hpi foi observado. Enquanto para o grupo predominantemente B. taurus $52,1 \%$ e $58,9 \%$ dos embriões divididos após 48 e 72 hpi respectivamente. Oócitos imaturos mostraram gotas lipídicas mais pequenas ( $\mathrm{p}<0,0001$ ), em contraste com oócitos IVM com maior número de gotas lipídicas médias e grandes $(\mathrm{p}<0,0001)$. Oócitos predominantemente $B$. indicus mostraram mais gotas lipídicas pequenas $(\mathrm{p}=0,0005)$ e médias $(\mathrm{p}=0,005)$, enquanto que para as gotas lipídicas grandes não foram observadas diferenças significativas. Oócitos IVM tiveram maior atividade mitocondrial que o grupo de oócitos imaturos $(\mathrm{p}<0,05)$, não houve efeito de predominância fenotípica sobre este parâmetro. A avaliação do conteúdo lipídico não foi um preditor de qualidade dos oócitos nas vacas mestiças.

Palabras-Chave: Qualidade oocitária, conteúdo lipídico, predominância fenotípica, Bos indicus, Bos taurus.

\section{CONTENIDO LIPÍDICO, ACTIVIDAD MITOCONDRIAL Y DESARROLLO EMBRIONARIO TEMPRANO DE OVOCITOS PROVENIENTES DE VACAS MESTIZAS (Bos taurus indicus)}

\section{RESUMEN}

El objetivo de la presente investigación fue el de valorar el efecto de la predominancia fenotípica sobre el contenido lipídico como indicador de la calidad ovocitaria. Los COC's fueron recuperados mediante aspiración folicular y sometidos a maduración in vitro (MIV), fecundación in vitro (FIV) y cultivo in vitro (CIV). Se determinó el contenido lipídico y actividad mitocondrial en ovocitos inmaduros y MIV. La tasa de maduración total se ubicó en $75 \%$, con valores de $80,6 \%$ y $69,3 \%$ para ovocitos predominantemente B. indicus y predominantemente $B$. taurus, respectivamente. La tasa de fecundación total fue de 27,6\%, para ovocitos predominantemente $B$. indicus y predominantemente $B$. taurus, esta fue de $26,1 \%$ y $29 \%$, respectivamente. Se observó un total de embriones divididos de $52,1 \%$ y $58,9 \%$ tras 48 y 72 horas post inseminación (hpi), respectivamente. Por otro lado, para el grupo predominantemente $B$. indicus se apreció un $55,5 \%$ y $57,5 \%$ de embriones divididos tras 48 y 72 hpi. Mientras que para el grupo predominantemente B. taurus se apreció un $52,1 \%$ y $58,9 \%$ de embriones divididos tras 48 y 72 hpi. Ovocitos inmaduros presentaron mayor número de gotas lipídicas pequeñas ( $\mathrm{p}<0,0001$ ), en contraste con los ovocitos MIV que presentaron mayor número de gotas lipídicas medianas y grandes $(\mathrm{p}<0,0001)$. Ovocitos predominantemente $B$. indicus presentaron mayor número de gotas lipídicas pequeñas $(\mathrm{p}=$ $0,0005)$ y medianas $(\mathrm{p}=0.005)$, mientras que para las gotas lipídicas grandes no se apreciaron diferencias significativas. Ovocitos MIV presentaron mayor actividad mitocondrial que el grupo de ovocitos inmaduros $(\mathrm{p}<0,05)$, sin observarse efecto de la predominancia fenotípica sobre este parámetro. La valoración del contenido lipídico no resultó un factor predictivo de la calidad ovocitaria en hembras mestizas.

Palabras clave: Calidad ovocitaria, contenido lipídico, predominancia fenotípica, Bos indicus, Bos taurus.

Mendez Y, Parra N, Baez F, Valeis R, Villamediana P. Lipid content, mitochondrial activity and early embryo development in oocyte collected from crossbred cows (Bos taurus indicus). Vet. e Zootec. 2018 mar.; 25(1): 120-131. 


\section{INTRODUCTION}

Intracellular lipids are a substrate that can be used as a source of energy during invitro embryo production (IVP) $(1,2)$. Thus, alterations in the quantity and the type of lipid species may result in a decrease of competence in oocyte development (3), being a paramount condition for the success in IVP, as are sperm quality and culture system (4,5). Leroy et al. (6) reported that IVM oocytes matured under fatty acid concentrations similar to those of follicular fluid from dairy cows undergoing negative energy balance, showed a decrease in maturation, fertilization, cleavage, and blastocyst rates. Furthermore, the increase in lipid content may induce mitochondrial dysfunction, which results in abnormal chromosome segregation, alterations in mitochondrial morphology, distribution, and membrane potential, along with an increase in lipid droplets $(7,8,9)$.

Oocyte quality is a major factor in the success of reproductive biotechnology implementation. Several studies resulted in the selection of morphologic and biochemical parameters that contribute as a whole to determine oocyte development competence. Recently, attention has been focused to the study of lipid content as an indicator of oocyte quality, due to the possibility of taking advantage of an endogenous energy source during IVP and the susceptibility to cryotolerance related to an increase in lipid droplets (10). An increment in concentration and variation of the composition of free fatty acids in the oocyte may impair its developmental competence $(3,6)$.

In western Venezuela, dual-purpose cattle husbandry has been developed. It has resulted in crossbreeding programs mainly alternating B. taurus and B. indicus, with the aim of producing an animal capable of adapting to the particular environmental conditions of the tropics (11). Moreover, the effect of phenotypic predominance on oocyte quality is paramount for cattle husbandry in the tropics. Oocytes from predominantly B. indicus cows are more competent in the early stages of development in vitro than oocytes from cows with phenotypic predominance $B$. taurus in tropical settings (12).

Several studies have aimed to increase the success of IVP systems, from improvements in recollection methods of oocytes to the design of culture media similar to the physiological conditions in cows. However, few studies have focused on the effect of lipid content and mitochondrial activity over oocyte development competence, and especially in their relation with phenotypic component in tropical crossbred cows.

\section{MATERIALS AND METHODS}

\section{Selection of females in the slaughterhouse}

Before slaughter, all cow and heifer was classified according to grade crossing and phenotypic ratio according Isea-Villasmil e Aranguren-Méndez (13). Only animals with phenotypic predominances above 5/8 Bos taurus and Bos indicus were included in one of two groups, phenotypic predominance Bos taurus and Bos indicus, respectively.

\section{Oocyte collection and IVM}

Ovaries were collected from local slaughterhouses, in an area that has characteristics of tropical wet forest with annual rainfall between 550-1500 mm. After collection, ovaries were transported within 2 hto the laboratory in $0.9 \% \mathrm{NaCl}(\mathrm{w} / \mathrm{v})$ at $35-37^{\circ} \mathrm{C}$. For this study, bovine oocytes obtained from predominantly $B$. indicus $(\mathrm{n}=367)$ and predominantly $B$. taurus $(n=369)$ crossbred cows, were used. COCs were recovered by aspiration of all visible follicles 
(2-8 mm) and resuspended in TCM-199 (11150-059, Gibco Life Technologies, Grand Island, NY, USA) supplemented with $\mathrm{NaHCO}_{3}(2.2 \mathrm{mg} / \mathrm{L})$, gentamicin sulfate $(50 \mu \mathrm{g} / \mathrm{mL})$, BSA $(0.4$ $\mathrm{g} / \mathrm{L})$, HEPES $(25 \mathrm{Mm})$ and heparin $(11.1 \mu \mathrm{g} / \mathrm{mL})$. Oocytes enclosed in a compact cumulus with an evenly granulated cytoplasm were selected. Groups of 25 COCs were IVM in $100 \mu \mathrm{L}$ drops of TCM-199 supplemented with $\mathrm{FSH}\left(0.5 \mu \mathrm{g} / \mathrm{ml}\right.$, Folltropin- $\mathrm{V}^{\circledR}$, Bioniche $), 17 \beta$ estradiol $(1 \mu \mathrm{g} / \mathrm{mL})$ gentamicin sulfate $(25 \mu \mathrm{g} / \mathrm{mL})$ and $10 \%$ fetal calf serum (FCS) in plates covered by mineral oil. COCs were cultured for $23 \mathrm{~h}$ at $38.5{ }^{\circ} \mathrm{C}$ in an atmosphere with $5 \%$ $\mathrm{CO}_{2}$ in air saturated humidity.

\section{Sperm preparation and IVF}

Frozen semen from a single bull (Bos taurus) were thawed at $37^{\circ} \mathrm{C}$ for $30 \mathrm{sec}$ and washed in a 15 Falcon tube using Percoll ${ }^{\circledR}$ gradients of $45 \%$ and $90 \%$ prepared with Tyrode's Albumin Lactate Pyruvate (TALP) solution $\left(2 \mathrm{~mL}\right.$ of $45 \%$ Percoll $^{\circledR}$ at the top and $2 \mathrm{~mL}$ of $90 \%$ Percoll $^{\circledR}$ in the bottom of the tube) by centrifugation at $325 \mathrm{~g}$ for $15 \mathrm{~min}$; then the pellet was diluted with $0.5 \mathrm{~mL}$ TALP solution and centrifuged a second time at $325 \mathrm{~g}$ for $10 \mathrm{~min}$. After maturation, batches of COCs were fertilized in $100 \mu \mathrm{L}$ Talp Fert medium containing $0.6 \%$ fraction $\mathrm{V}$ fatty acid free BSA, $10 \mu \mathrm{g} / \mathrm{mL}$ heparin, $20 \mathrm{mM}$ penicillamine, $10 \mathrm{mM}$ hypotaurine, and $1 \mathrm{mM}$ epinephrine. Spermatozoa were added to a concentration of $1 \times 10^{6}$ spermatozoa/mL. COCs and spermatozoa were incubated for $18 \mathrm{~h}$ at $38.5{ }^{\circ} \mathrm{C}$ under an atmosphere with $5 \% \mathrm{CO}_{2}$ in air saturated humidity.

\section{IVC}

Presumptive zygotes were denuded of cumulus cells by manual pipetting. Droplets of $50 \mu \mathrm{L}$ of modified synthetic oviduct fluid with amino acids, citrate and myo-inositol (mSOFaaci) supplemented with fatty acid free BSA $(6 \mathrm{mg} / \mathrm{mL})$, sodium pyruvate $(11 \mathrm{mg} / \mathrm{mL})$ and gentamicin sulfate $(50 \mu \mathrm{g} / \mathrm{mL})$ were layered under mineral oil and embryos cultured in group of 25 at $38.5^{\circ} \mathrm{C}$ in $5 \% \mathrm{CO}_{2}$ in air saturated humidity. The embryos were cultured for 3 days.

\section{Oocytes denudation}

Cumulus cells were mechanically removed from intact COCs by repeated pipetting with PBS supplemented with BSA $(3 \mathrm{mg} / \mathrm{mL})$. Dispersion of cumulus was verified by a stereoscopic microscope.

\section{Assessment of lipid content}

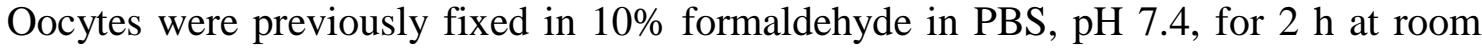
temperature. After fixation, they were washed in distilled water containing $0.05 \%$ polivinylalcohol (PVA) and then transferred to drops of 50\% ethanol. After 2 min, oocytes were stained in drops of $1 \%$ Sudan Black B (w/v; S668, Fisher) in 70\% ethanol for 1-2 min, then they were washed three times with $50 \%$ ethanol, $5 \mathrm{~min}$ each, followed by a 5 min wash in $0.05 \%$ PVA in distilled water. Prepared oocytes were mounted in $10 \mu \mathrm{L}$ glycerol on cover slips and examined under a light microscope at $600 \mathrm{X}$ magnification. To estimate the relative amount of lipid droplets in the cytoplasm in each oocyte, a grid with five squares of 1,600 $\mu \mathrm{m}^{2}(40 \mathrm{x} 40 \mu \mathrm{m})$ each was designed using ImageJ 14.1 software. Lipid droplets were classified as small, medium, and large $(<2 \mu \mathrm{m}, 2-6 \mu \mathrm{m}$, and $>6 \mu \mathrm{m}$, respectively). The number of droplets per category in the $1,600 \mu \mathrm{m}^{2}$ square was counted, and the average 
number of droplets from five squares for each embryo was calculated. Data regarding lipid accumulation are presented as number of lipid droplets per $1,000 \mu \mathrm{m}^{2}(14)$.

\section{Evaluation of mitochondrial activity in oocytes}

Oocytes were stained with $0.02 \%$ Janus Green B in maturation medium and maintained at $38.5^{\circ} \mathrm{C}$ in an atmosphere with $5 \% \mathrm{CO}_{2}$ in humidity saturated air for $30 \mathrm{~min}$. After several washes in PBS and PVA $(0.1 \mathrm{mg} / \mathrm{mL})$, oocytes were observed under light microscope $(600 \mathrm{X})$ (15). To estimate mitochondrial activity, a photograph of each oocyte was taken and processed with Adobe ${ }^{\circledR}$ Photoshop ${ }^{\circledR}$ CS6 software. Color photographs of oocytes were converted to gray scale images and the average gray intensity (arbitrary units) was obtained.

\section{Nuclear maturation}

After denudation, oocytes were fixed with methanol + acetic acid $(3: 1)$ for $48 \mathrm{~h}$ at $4^{\circ} \mathrm{C}$, stained with $1 \%$ solution of lacmoid in $45 \%$ glacial acetic acid, evaluated under an optical microscope (Olympus CX31, Japan ${ }^{\circledR}$ ) (400X), and classified according to the meiotic stage reached: mature (metaphase II + polar body, telophase I) and immature (anaphase I, metaphase I, chromosomal condensation and in GV). Oocytes that could not be included in previous groups were considered as degenerate.

\section{Assessment of fertilization and cleavage rate}

To evaluate the fertilization rate, oocytes were removed from culture at $17 \mathrm{hpi}$ and fixed and stained as described in the previous section. Oocytes were examined under an optical microscope (Olympus CX31, Japan ${ }^{\circledR}$ ) and classified as either (a) non fertilized - the presence of female and the absence of male chromatin; (b) normal fertilized: the presence of female and male chromatin in the cytoplasm, a decondensed sperm head, pronuclei or cleavage; (c) abnormal fertilized: asynchronous oocytes (marked alteration in the formation of pronuclei, as undecondensed sperm head or telophase II) and $>2$ pronuclei (oocytes in which more than 2 pronuclei were observed in the cytoplasm); or (d) degenerate oocytes. Cleavage rate was evaluated at 48 and $72 \mathrm{hpi}$, taking into account the total of embryos of 2 or more cells obtained in relation to the total of oocytes that were fertilized. All embryos were observed under stereoscopic microscope (Olympus, SZX12, Japan ${ }^{\circledR}$ ).

\section{Experimental design}

Oocytes obtained from each of the phenotypic predominance were divided into two groups, the first group (GI) corresponding to immature oocytes were fixed and stained for evaluation of lipid content and mitochondrial activity. The second group (GII) were oocytes for IVM, from which a pooled sample of 10 oocytes in each group were used for the evaluation of meiotic progression, lipid content and mitochondrial activity. The rest of IVM oocytes (GII) were used in IVF, and a pooled sample of 10 oocytes of each group were fixed for the evaluation of fertilization rate after 17 hpi. Finally, cleavage rate after 48 and 72 hpi was assessed.

\section{Statistical analysis}

Mendez Y, Parra N, Baez F, Valeis R, Villamediana P. Lipid content, mitochondrial activity and early embryo development in oocyte collected from crossbred cows (Bos taurus indicus). Vet. e Zootec. 2018 mar.; 25(1): 120-131. 
Nuclear state, fertilization and cleavage rate were expressed as frequencies and analyzed using the Chi-square test. Lipid content and mitochondrial activity were expressed as mean \pm SD and analyzed using General Linear Model (GLM PROC) and statistical LSMEANS of the SAS ${ }^{\circledR}$ Version 8.2 software (1999; SAS ${ }^{\circledR}$ Institute Inc., Cary, NC, USA). A value of $\mathrm{p}<0.05$ was considered to be statistically significant.

\section{RESULTS}

A total of 736 oocytes were included in this study; 367 oocytes represented the experimental group with $B$. indicus phenotypic predominance, and 369 oocytes represented the experimental group with $B$. taurus phenotypic predominance. Eighty-eight oocytes were analyzed for lipid content (Table 1). Immature oocytes showed a greater amount of small lipiddroplets; this condition changed as oocytes reached maturation, having a cytoplasm richer in medium and large lipid droplets ( $\mathrm{p}<0.0001)$. No significant differences in large lipid droplets were found due to phenotypic predominance.

Table 1. Lipid content in immature and IVM oocytes from cows with phenotypic predominance of B. indicus and B. taurus.

\begin{tabular}{|l|c|c|c|c|c|}
\hline \multirow{2}{*}{ Stage } & Predominance & $\begin{array}{c}\text { Total of } \\
\text { evaluated } \\
\text { oocytes }\end{array}$ & $\begin{array}{c}\text { Small droplets } \\
<\mathbf{2} \boldsymbol{\mu m}\end{array}$ & $\begin{array}{c}\text { Medium-sized } \\
\text { droplets } \\
\mathbf{2} \mathbf{~ a ~} \mathbf{\mu m}\end{array}$ & $\begin{array}{c}\text { Large droplets } \\
>\mathbf{6} \boldsymbol{\mu m}\end{array}$ \\
\hline \multirow{4}{*}{$\begin{array}{l}\text { Immature } \\
\text { oocytes }\end{array}$} & $\boldsymbol{B}$. indicus & $\mathbf{2 9}$ & $74.7 \pm 37.1^{\mathrm{a}}$ & $12.4 \pm 12.2^{\mathrm{ab}}$ & $0.1 \pm 0.3^{\mathrm{a}}$ \\
\cline { 2 - 6 } & $\boldsymbol{B}$. taurus & $\mathbf{2 6}$ & $41.7 \pm 27.6^{\mathrm{b}}$ & $7.5 \pm 6.8^{\mathrm{a}}$ & $0.2 \pm 0.5^{\mathrm{a}}$ \\
\cline { 2 - 6 } & Total & $\mathbf{5 5}$ & $59.1 \pm 36.6^{\mathrm{x}}$ & $10.1 \pm 10.2^{\mathrm{y}}$ & $0.2 \pm 0.4^{\mathrm{y}}$ \\
\hline \multirow{3}{*}{$\begin{array}{l}\text { IVM } \\
\text { oocytes }\end{array}$} & B. indicus & $\mathbf{1 5}$ & $21.6 \pm 12.5^{\mathrm{bc}}$ & $26.4 \pm 11.2^{\mathrm{c}}$ & $2.1 \pm 1.1^{\mathrm{b}}$ \\
\cline { 2 - 6 } & B. taurus & $\mathbf{1 8}$ & $8.6 \pm 9.4^{\mathrm{cd}}$ & $17.8 \pm 8.7^{\mathrm{bc}}$ & $2.4 \pm 1.4^{\mathrm{b}}$ \\
\cline { 2 - 6 } & Total & $\mathbf{3 3}$ & $14.5 \pm 12.6^{\mathrm{y}}$ & $21.7 \pm 10.7^{\mathrm{x}}$ & $2.3 \pm 1.3^{\mathrm{x}}$ \\
\hline
\end{tabular}

Mean \pm SD. Lipid droplets $/ 10^{3} \mu \mathrm{m}^{2}$. a,b,c,d Values within the same column with different superscripts differ $(\mathrm{p}<$ 0.0005). ${ }^{\mathrm{x}, \mathrm{y}}$ Values within the same column with different superscripts differ $(\mathrm{p}<0.0001)$.

IVM oocytes showed greater mitochondrial activity (128.5 AU) than immature oocytes (133.9 AU). On the other hand, there was no effect of phenotypic predominance on this parameter (Table 2).

Table 2. Mitochondrial activity in bovine immature and IVM oocytes from cows with phenotypic predominance of B. indicus and B. taurus.

\begin{tabular}{|l|c|c|c|}
\hline \multirow{4}{*}{ Stage } & Predominance & $\begin{array}{c}\text { Total of evaluated } \\
\text { oocytes }\end{array}$ & Gray scale intensity \\
\hline \multirow{3}{*}{ Immature oocytes } & B. indicus & $\mathbf{2 4}$ & $131.4 \pm 11.2$ \\
\cline { 2 - 4 } & B. taurus & $\mathbf{2 6}$ & $136.3 \pm 9$ \\
\cline { 2 - 4 } & Total & $\mathbf{5 0}$ & $133.9 \pm 10.3^{\mathrm{b}}$ \\
\hline \multirow{3}{*}{ IVM oocytes } & B. indicus & $\mathbf{1 5}$ & $128.9 \pm 15$ \\
\cline { 2 - 4 } & B. taurus & $\mathbf{1 7}$ & $128.1 \pm 12.5$ \\
\cline { 2 - 4 } & Total & $\mathbf{3 2}$ & $128.5 \pm 13.5^{\mathrm{a}}$ \\
\hline
\end{tabular}

Mean \pm SD. Arbitrary units. a,b Values within the same column with different superscripts differ $(\mathrm{p}<0.05)$.

Mendez Y, Parra N, Baez F, Valeis R, Villamediana P. Lipid content, mitochondrial activity and early embryo development in oocyte collected from crossbred cows (Bos taurus indicus). Vet. e Zootec. 2018 mar.; 25(1): $120-131$. 
Maturation rate for predominantly $B$. indicus oocytes was $80.6 \%$, whereas for the predominantly $B$. taurus group it was $69.3 \%$. A $3.3 \%$ and $6.5 \%$ incidence of degenerate oocytes for predominantly $B$. indicus and predominantly B. taurus groups was observed, respectively. There were no significant differences in the above-mentioned parameters (Table $3)$.

Table 4 displays data corresponding the assessment of bovine oocyte fertilization, wherein a total of 145 presumptive zygotes were taken into account. The predominantly $B$. indicus group had $26.1 \%$ normal fertilized oocytes. As for the group predominantly B. taurus, $29 \%$ normal fertilized oocytes and $2.6 \%$ of degenerate oocytes, without any significant differences in any case.

Table 3. Nuclear maturation of bovine oocytes from cows with phenotypic predominance of B. indicusand B. taurus.

\begin{tabular}{|c|c|c|c|c|c|c|c|c|c|}
\hline \multirow[b]{2}{*}{ Predominance } & \multirow{2}{*}{$\begin{array}{l}\text { Total of } \\
\text { evaluate } \\
\text { d oocytes }\end{array}$} & \multicolumn{3}{|c|}{$\mathbf{N}^{\circ}$ of mature oocytes } & \multicolumn{4}{|c|}{$\mathbf{N}^{\circ}$ of immature oocytes } & $\begin{array}{c}\mathbf{N}^{\circ} \\
\text { Deg. }\end{array}$ \\
\hline & & $\begin{array}{c}\text { Total } \\
\text { n } \\
(\%) \\
\end{array}$ & $\begin{array}{c}\text { TeloI } \\
\text { n } \\
(\%)\end{array}$ & $\begin{array}{c}\text { MII+CP } \\
\text { n } \\
(\%) \\
\end{array}$ & $\begin{array}{c}\text { Total } \\
\text { n } \\
(\%)\end{array}$ & $\begin{array}{c}\text { GV } \\
\text { n } \\
(\%)\end{array}$ & $\begin{array}{c}\text { MI } \\
\text { n } \\
(\%) \\
\end{array}$ & $\begin{array}{c}\text { AnaI } \\
\text { n } \\
(\%)\end{array}$ & $\begin{array}{c}\mathrm{n} \\
(\%)\end{array}$ \\
\hline B. indicus & 62 & $\begin{array}{c}50 \\
(\mathbf{8 0 . 6})\end{array}$ & $\begin{array}{c}1 \\
(1.6)\end{array}$ & $\begin{array}{c}49 \\
(79)\end{array}$ & $\begin{array}{c}10 \\
(16.1)\end{array}$ & $\begin{array}{c}1 \\
(1.6)\end{array}$ & $\begin{array}{c}8 \\
(12.9)\end{array}$ & $\begin{array}{c}1 \\
(1.6)\end{array}$ & $\begin{array}{c}2 \\
(3.3)\end{array}$ \\
\hline B. taurus & 62 & $\begin{array}{c}43 \\
(69.3)\end{array}$ & $\begin{array}{c}2 \\
(3.2)\end{array}$ & $\begin{array}{c}41 \\
(66.1)\end{array}$ & $\begin{array}{c}15 \\
(24.2)\end{array}$ & 0 & $\begin{array}{c}15 \\
(24.2)\end{array}$ & 0 & $\begin{array}{c}4 \\
(6.5)\end{array}$ \\
\hline Total & 124 & $\begin{array}{c}93 \\
(75)\end{array}$ & $\begin{array}{c}3 \\
(2.4)\end{array}$ & $\begin{array}{c}90 \\
(72.5)\end{array}$ & $\begin{array}{c}25 \\
(20.2)\end{array}$ & $\begin{array}{c}1 \\
(0.8)\end{array}$ & $\begin{array}{c}23 \\
(18.5)\end{array}$ & $\begin{array}{c}1 \\
(0.8)\end{array}$ & $\begin{array}{c}6 \\
(4.8)\end{array}$ \\
\hline
\end{tabular}

TeloI: Telophase I. MII+CP: Metaphase II + polar body. GV: Germinal vesicle. MI: Metaphase I. AnaI: Anaphase I. $\mathrm{N}^{\circ}$ Deg: degenerate oocytes.

Table 4. Assessment of fertilization in bovine oocytes from cows with phenotypic predominance of B. indicus and B. taurus

\begin{tabular}{|c|c|c|c|c|c|c|c|}
\hline \multirow[b]{2}{*}{ Predominance } & \multirow[b]{2}{*}{$\begin{array}{c}\text { Total of } \\
\text { evaluated } \\
\text { presumpti } \\
\text { ve zygotes }\end{array}$} & \multicolumn{5}{|c|}{$\mathbf{N}^{\circ}$ of adnormal fertilized oocytes } & \multirow{2}{*}{$\begin{array}{c}\mathbf{N}^{\circ} \text { Deg. } \\
\mathbf{n} \\
(\%)\end{array}$} \\
\hline & & $\begin{array}{c}\text { Non Fert. } \\
\text { Oocytes } \\
\mathbf{n} \\
(\%) \\
\end{array}$ & $\begin{array}{c}\text { Norm. Fert. } \\
\text { Oocytes } \\
\text { n } \\
(\%) \\
\end{array}$ & $\begin{array}{c}\text { Activated } \\
\text { n } \\
(\%)\end{array}$ & $\begin{array}{c}\text { Async. } \\
\text { n } \\
(\%)\end{array}$ & $\begin{array}{c}>2 P N \\
\text { n } \\
(\%)\end{array}$ & \\
\hline B. indicus & 69 & $\begin{array}{c}45 \\
(65.2)\end{array}$ & $\begin{array}{c}18 \\
(26.1)\end{array}$ & $\begin{array}{c}3 \\
(\mathbf{4 . 3})\end{array}$ & $\mathbf{0}$ & $\mathbf{0}$ & $\begin{array}{c}3 \\
(\mathbf{4 . 4})\end{array}$ \\
\hline B. taurus & 76 & $\begin{array}{c}47 \\
(61.8)\end{array}$ & $\begin{array}{c}22 \\
(29)\end{array}$ & $\begin{array}{c}2 \\
(2.6)\end{array}$ & $\begin{array}{c}2 \\
(2.6)\end{array}$ & $\begin{array}{c}1 \\
(1.3)\end{array}$ & $\begin{array}{c}2 \\
(2.6)\end{array}$ \\
\hline Total & 145 & $\begin{array}{c}92 \\
(63.4)\end{array}$ & $\begin{array}{c}40 \\
(27.5)\end{array}$ & $\begin{array}{c}5 \\
(3.4)\end{array}$ & $\begin{array}{c}2 \\
(1.3)\end{array}$ & $\begin{array}{c}1 \\
(0.6)\end{array}$ & $\begin{array}{c}5 \\
(3.4)\end{array}$ \\
\hline
\end{tabular}

Non Fert. Oocytes: non fertilized oocytes. Norm. Fert. Oocytes: normal fertilized oocytes. Async: asynchronous oocytes. >2PN: oocytes with more than 2 pronuclei. Deg: degenerate oocytes.

The evaluation of embryo development was performed. After 48 and $72 \mathrm{hpi}, 52.1 \%$ and $58.9 \%$ of total cleaved embryos, respectively, were observed (Table 5). The predominantly $B$. indicus group showed $55.5 \%$ and $57.5 \%$ cleaved embryos after 48 and 72 hpi, respectively; whereas, the predominantly B. taurus group had $48.6 \%$ and $60.4 \%$ cleaved embryos after 48 and 72 hpi, respectively. No statistically significant differences were observed.

Mendez Y, Parra N, Baez F, Valeis R, Villamediana P. Lipid content, mitochondrial activity and early embryo development in oocyte collected from crossbred cows (Bos taurus indicus). Vet. e Zootec. 2018 mar.; 25(1): $120-131$ 
Table 5. Evaluation of embryo development of bovine oocytes from cows with phenotypic predominance of B. indicus and B. taurus.

\begin{tabular}{|c|c|c|c|c|c|c|c|}
\hline Predominance & $\begin{array}{l}\text { Total } \\
\text { zygotes in } \\
\text { IVC }\end{array}$ & $\begin{array}{c}\text { Total } \\
\text { cleaved } \\
\text { embryos } \\
48 \text { hpi n } \\
(\%)\end{array}$ & $\begin{array}{c}2 \text { Cells } \\
\text { n }\end{array}$ & $\begin{array}{c}>2 \\
\text { Cells } \\
\text { n }\end{array}$ & $\begin{array}{c}\text { Total } \\
\text { cleaved } \\
\text { embryos } \\
72 \text { hpi } \\
\text { n } \\
(\%)\end{array}$ & $\begin{array}{c}2 \text { Cells } \\
\text { n }\end{array}$ & $\begin{array}{c}>2 \text { Cells } \\
\mathrm{n}\end{array}$ \\
\hline B. indicus & 153 & $\begin{array}{c}85 \\
(55.5)\end{array}$ & 35 & 50 & $\begin{array}{c}88 \\
(57.5)\end{array}$ & 20 & 68 \\
\hline B. taurus & 144 & $\begin{array}{c}70 \\
(48.6)\end{array}$ & 27 & 43 & $\begin{array}{c}87 \\
(60.4)\end{array}$ & 20 & 67 \\
\hline Total & 297 & $\begin{array}{c}155 \\
(52.1)\end{array}$ & 62 & 93 & $\begin{array}{c}175 \\
(58.9)\end{array}$ & 40 & 135 \\
\hline
\end{tabular}

\section{DISCUSSION}

Research focusing on determination of lipid content in bovine oocytes is scarce, especially in $B$. indicus oocytes. This study presents the first findings for quantification and dynamics of lipid droplets in oocytes from crossbred cows. In this research, it was observed that lipid content was affected by both phenotypic predominance and maturation stage of the oocyte. A previous study by Ballard et al. (16), reported the presence of oocytes with greater amount of lipid content in $B$. indicus cows, having in turn higher levels of cholesterol and triglycerides in blood compared with $B$. taurus cows, which suggests the use of these indicators as predictive parameters of oocyte lipid content. By contrast, Ordóñez-León et al. (17) observed a greater amount of lipid droplets in B. taurus oocytes, followed by $B$. indicus $\mathrm{X}$ $B$. taurus, and finally $B$. indicus oocytes. As to maturation stage, immature oocytes showed greater amounts of lipid droplets; an abundance of small lipid droplets could be observed. This condition varied toward an increase in the presence of medium-sized and large droplets as MII was reached. Those results coincide with the findings of Hyttel et al. (18) who reported that the number, size, and distribution of lipid droplets change during oocyte maturation: immature oocytes have small lipid droplets, whereas mature oocytes have larger droplets.

The recognition of lipid droplets as functional organelles in the cell that participate in the regulation of lipid storage and metabolism is quite recent (19). Moreover, models trying to reveal the mechanisms of biogenesis and growth of these structures are continually modified and updated. There are at least three models that seek to explain the process of growth of lipid droplets: a) incorporation of neutral lipids and phospholipids to lipid droplets through domains having close contact with endoplasmic reticulum; b) lipid synthesis by the enzymatic machinery present in lipid droplets; c) fusion of preexistent lipid droplets (20).

The findings of this research seem to support the model of fusion of lipid droplets $(19,20)$. In this case, small lipid droplets are abundantly found in immature oocytes $\left(59 \cdot 1 / 10^{3}\right.$ $\left.\mu \mathrm{m}^{2}\right)$, whereas medium-sized $\left(10.1 / 10^{3} \mu \mathrm{m}^{2}\right)$ and large $\left(0.2 / 10^{3} \mu \mathrm{m}^{2}\right)$ droplets are found in lesser amounts. After IVM, a decrease in the total number of lipid droplets occurred, but the amount of medium-sized $\left(21.7 / 10^{3} \mu \mathrm{m}^{2}\right)$ and large $\left(2.3 / 10^{3} \mu \mathrm{m}^{2}\right)$ lipid droplets increased (Table 1), in such a way that it is possible that the decrease in the total amount of lipid droplets is related to the fusion of small droplets that would integrate into larger droplets.

The presence of more lipid content in immature oocytes is associated with a greater number of mitochondria, higher division and blastocyst rate and greater numbers of total cells (21). Lipids in the oocyte may play a paramount role in its metabolism, due to the fact that triglyceride concentrations have been observed to decline in female gamete afterIVM, and the

Mendez Y, Parra N, Baez F, Valeis R, Villamediana P. Lipid content, mitochondrial activity and early embryo development in oocyte collected from crossbred cows (Bos taurus indicus). Vet. e Zootec. 2018 mar.; 25(1): $120-131$ 
inhibition of fatty acid oxidation during IVM results in alteration of embryo development $(1,2)$.

In this research, mitochondrial activity was not affected by phenotypic predominance. No report about this parameter in oocytes from crossbred cows could be found. However, Esper and Barboza (In: 17), observed that IVP B. indicus embryos had a greater number of mitochondria than B. taurus embryos. Moreover, B. indicus oocytes had greater lipid content and tended to show higher mitochondrial activity after cows were administered fat enriched diets (22).

On the other hand, oocyte maturation stage is a factor that influences that parameter, IVM oocytes having higher mitochondrial activity than immature oocytes. These results coincide with previous studies wherein higher concentrations of ATP are observed in oocytes at MII $(23,24,25)$. According to this, evaluation of oocyte morphology revealed that this trait is related to oocyte mitochondrial activity $(23,24)$. Immature oocytes with brownish cytoplasm would have the ideal amount of lipid droplets and ATP to reach oocyte maturation; oocytes with pale cytoplasm would have few lipid droplets and lower concentrations of ATP, and finally, oocytes with dark cytoplasm would have a high amount of lipid droplets as well as high concentrations of ATP. Oocytes with high concentrations of ATP in the cytoplasm have a lower rate of first polar body extrusion after they are subjected to IVM, whereas those with low levels of ATP could reach blastocyst stage with a low number of cells (24).

Oocytes from predominantly $B$. indicus and predominantly $B$. taurus cows showed maturation rates of $80.6 \%$ and $69.3 \%$, respectively. By contrast, Báez et al. (12) reported values of $66.17 \%$ and $50.94 \%$ for oocytes from predominantly B. indicus and predominantly $B$. taurus cows, respectively. Fertilization rate was not affected by oocyte lipid content. That was also the conclusion of Cerri et al. (26), who administered diets enriched with fatty acids from different sources to cows without observing significant variations in fertilization rates. Leroy et al. (6) observed that IVM in the presence of stearic or palmitic acids had no influence on oocyte lipid content, but resulting in decreasing fertilization rates, maybe as part of a collateral effect mediated by alterations of oocyte maturation.

Mitochondrial activity, determined by oxygen consumption and reactive oxygen species (ROS) production, is augmented during fertilization process in bovine oocytes and it is related to pronuclei formation (27). On the other hand, swine oocytes with positive staining for bright cresyl blue had a greater number of mitochondrial DNA copies and higher fertilization rates than those negative to that stain (28). However, Ge et al. (29) reported that oxidative phosphorylation inhibition, even though it diminishes mitochondrial membrane potential and ATP synthesis, has no effect on murine oocytes fertilization rates; in this case it is probable that the inhibitory effect was not enough to cause a critical decrease in ATP concentrations.

Camargo et al. (30) found differences between racial groups, so that oocytes from $B$. indicus cows showed higher cleavage rates than those from $B$. taurus cows, with values of $66.7 \%$ and $53.1 \%$, respectively. However, Paula-Lopes et al. (31) and Hernández-Cerón et al. (32) failed to detect differences in cleavage rates between oocytes from B. taurus, tropicalized B. taurus, and B. indicus at $38.5^{\circ} \mathrm{C}$.

A slight increase in oxygen consumption is seen during the beginning of the first embryo cleavage, along with an increase in ROS concentrations, which is an indicator of the mitochondrial activity needed to meet the energy demand inherent to embryo cleavage (27). It is well known that the inhibition of oxidative phosphorylation and the decrease in the amount of mitochondrial DNA copies induce the decline of blastocyst rates in bovines in a dosedependent way possibly due to the decrease in ATP concentrations by alterations in mitochondria distribution, and by mitotic spindle disarrangement (29). Culture media supplementation with L-carnitine augments ATP content in the oocyte and induces lipid

Mendez Y, Parra N, Baez F, Valeis R, Villamediana P. Lipid content, mitochondrial activity and early embryo development in oocyte collected from crossbred cows (Bos taurus indicus). Vet. e Zootec. 2018 mar.; 25(1): $120-131$. 
droplets redistribution (33), as well as increases blastocyst rates (34) and enhances embryo development competence after vitrification (33).

The oocyte meiotic stage affects mitochondrial activity; IVM oocytes had higher mitochondrial activity that immature oocytes. Phenotypic predominance had no effect on this parameter. Studies undertaken to date have surmised the possibility of establishing lipid content determination as an indicator of oocyte quality. However, this research has proved that lipid content in slaughterhouse-derived oocytes determined through lipid droplets quantification vary according to phenotypic predominance, but they are not related to oocyte competence in crossbred cows; therefore, lipid content does not qualify as a parameter predictive of oocyte development potential for IVP in the tropics. However, the effect of phenotypic predominance on oocyte lipid content and the existence of studies that indicate a relationship between genotype and cryopreservation susceptibility, it would be worthwhile to consider the effect that lipid content could have on post-thawing survival in oocytes and embryos obtained from crossbred (B. taurus indicus) cows.

\section{ACKNOWLEDGEMENTS}

This project was funded by CONDES-LUZ (CC-0054-13).

\section{REFERENCES}

1. Kim J, Kinoshita M, Ohnishi M, Fukui Y. Lipid and fatty acid analysis of fresh and frozen-thawed immature and in vitro matured bovine oocyte. Reproduction. 2001;122:131-8.

2. Ferguson E, Leese H. A potential role for triglyceride as an energy source during bovine oocyte maturation and early embryo development. Mol Reprod Dev. 2006;73:1195-201.

3. Aardema H, Vos P, Lolicato F, Roelen B, Knijn H, Vaandrager A, Helms J, Gadella B. Oleic acid prevents detrimental effects of saturated fatty acids on bovine oocyte developmental competence. Biol Reprod. 2011;85: 62-9.

4. Krisher R. The effect of oocyte quality on development. J Anim Sci. 2004;82:E14-23.

5. Boni R. Origins and effects of oocyte quality in cattle. Anim Reprod. 2012;9:333-40.

6. Leroy J, Vanholder T, Mateusen B, Christophe A, Opsomer A, de Kruif A, et al. Nonesterified fatty acids in follicular fluid of dairy cows and their effect on developmental capacity of bovine oocytes in vitro. Reproduction. 2005;130:485-95.

7. Igosheva N, Abramov A, Poston L, Eckert J, Fleming T, Duchen M, et al. Maternal dietinduced obesity alters mitochondrial activity and redox status in mouse oocyte and zygote. PLoS One. 2010;5:e10074.

8. Wu L, Dunning K, Yang X, Russell D, Lane M, Norman R, et al. High-fat diet causes lipotoxicity responses in cumulus-oocyte complexes and decreased fertilization rates. Endocrinology. 2010;151:5438-45.

9. Grindler N, Moley K. Maternal obesity, infertility and mitochondrial dysfunction: potential mechanisms emerging from mouse model systems. Mol Hum Reprod. 2013;19:486-94.

Mendez Y, Parra N, Baez F, Valeis R, Villamediana P. Lipid content, mitochondrial activity and early embryo development in oocyte collected from crossbred cows (Bos taurus indicus). Vet. e Zootec. 2018 mar.; 25(1): $120-131$ 
10. Leroy J, Genicot G, Donnay I, Van Soom A. Evaluation of the lipid content in bovine oocytes and embryos with nile red: a practical approach. Reprod Domest Anim.2005;40:76-8.

11. Aranguren-Méndez J, Yáñez L. Planifique los cruzamientos. In: González-Stagnaro C, Soto-Belloso E. Manual de ganadería doble propósito. Maracaibo: Ediciones Astro Data SA; 2005. p.119-24.

12. Báez F, Chávez A, Hernández H, Villamediana P. Evaluación de la capacidad de desarrollo in vitro de ovocitos bovinos provenientes de vacas con predominancia fenotípica Bos taurus y Bos indicus. Rev Cient. 2010;20(3):259-67.

13. Isea-Villasmil W, Aranguren-Méndez J. Clasificación fenotípica en vacas mestizas. In: González-Stagnaro C, Belloso ES. Manual de ganadería doble propósito. Maracaibo: Ediciones Astro Data SA; 2005. p.76-81.

14. Sudano M, Paschoal D, Rascado T, Lima J, Landim-Alvarenga F. The effect of fetal calf serum concentrations upon the in vitro Bos taurus indicus x Bos taurus taurus crossbred embryo production and the cytoplasmic lipid accumulation. Vet Zootec. 2011;18(1):12334.

15. Popescu L, Gherghiceanu M, Hinescu M, Cretoiu D, Ceafalan L, Regalia T, et al. Insights into the interstitium of ventricular myocardium: interstitial Cajal-like cells (ICLC). J Cell Mol Med. 2006;10(2):429-58.

16. Ballard C, Looney C, Lindsey B, Pryor J, Lynn J, Bondioli K, et al. Comparing oocyte lipid content with circulant cholesterol and triglyceride levels of Bos taurus and Bos indicus donor cows. Reprod Fertil Dev. 2008;20:177.

17. Ordóñez-León E, Merchant H, Medrano A, Kjelland M, Romo S. Lipid droplet analysis using in vitro bovine oocytes and embryos. Reprod Domest Anim. 2014;49(2):306-14.

18. Hyttel P, Fair T, Callesen H, Greve T. Oocyte growth, capacitation and final maturation in cattle. Theriogenology. 1997;47(1):23-32.

19. Farese R, Walther T. Lipid droplets finally get a little R-E-S-P-E-C-T. Cell. 2009;139(5):855-60.

20. Yang H, Galea A, Sytnyk V, Crossley M. Controlling the size of lipid droplets: lipid and protein factors. Curr Opin Cell Biol. 2012;24(4):509-19.

21. Jeong W, Cho S, Lee H, Deb G, Lee Y, Kwon T, et al. Effect of cytoplasmic lipid content on in vitro developmental efficiency of bovine IVP embryos. Theriogenology. 2009;72(4):584-9.

22. Castaneda C, Kaye P, Pantaleon M, Phillips N, Norman S, Fry R, et al. Lipid content, active mitochondria and brilliant cresyl blue staining in bovine oocytes. Theriogenology. 2013;79(3):417-22.

23. Stojkovic M, Machado S, Stojkovic P, Zakhartchenko V, Hutzler P, Goncalves P, et al. Mitochondrial distribution and adenosine triphosphate content of bovine oocytes before

Mendez Y, Parra N, Baez F, Valeis R, Villamediana P. Lipid content, mitochondrial activity and early embryo development in oocyte collected from crossbred cows (Bos taurus indicus). Vet. e Zootec. 2018 mar.; 25(1): $120-131$ 
and after in vitro maturation: correlation with morphological criteria and developmental capacity after in vitro fertilization and culture. Biol Reprod. 2001;64(3):904-9.

24. Nagano M, Katagiri S, Takahashi Y. ATP content and maturational/developmental ability of bovine oocytes with various cytoplasmic morphologies. Zygote. 2006;14(4):299-304.

25. Tarazona A, Rodríguez J, Restrepo L, Olivera-Ángel M. Mitochondrial activity, distribution and segregation in bovine oocytes and in embryos produced in vitro. Reprod Domest Anim. 2006;41(1):5-11.

26. Cerri R, Juchem S, Chebel R, Rutigliano H, Bruno R, Galvão K, et al. Effect of fat source differing in fatty acid profile on metabolic parameters, fertilization, and embryo quality in high-producing dairy cows. J Dairy Sci. 2009;92(4):1520-31.

27. Lopes A, Lane M, Thompson J. Oxygen consumption and ROS production are increased at the time of fertilization and cell cleavage in bovine zygotes. Hum Reprod. 2010;25(11):2762-73.

28. El Shourbagy S, Spikings E, Freitas M, John J. Mitochondria directly influence fertilization outcome in the pig. Reproduction. 2006;131:233-45.

29. Ge H, Tollner T, Hu Z, Dai M, Li X, Guan H, et al. The importance of mitochondrial metabolic activity and mitochondrial DNA replication during oocyte maturation in vitro on oocyte quality and subsequent embryo developmental competence. Mol Reprod Dev. 2012;79(6):392-401.

30. Camargo L, Viana J, Ramos A, Serapião R, de Sa W, Ferreira A, et al. Developmental competence and expression of the Hsp 70.1 gene in oocytes obtained from Bos indicus and Bos taurus dairy cows in a tropical environment. Theriogenology. 2007;68(4):62632 .

31. Paula-Lopes F, Chase C, Al-Katanani Y, Krininger C, Rivera R, Tekin S, et al. Genetic divergence in cellular resistance to heat shock in cattle: differences between breeds developed in temperate versus hot climates in responses of preimplantation embryos, reproductive tract tissues and lymphocytes to increased culture temperatures. Reproduction. 2003;125(2):285-94.

32. Hernández-Cerón J, Chase C, Hansen P. Differences in heat tolerance between preimplantation embryos from Brahman, Romosinuano, and Angus breeds. J Dairy Sci. 2004;87(1):53-8.

33. Chankitisakul V, Somfai T, Inaba Y, Techakumphu M, Nagai T. Supplementation of maturation medium with L-carnitine improves cryo-tolerance of bovine in vitro matured oocytes. Theriogenology. 2013;79(4):590-8.

34. Sutton-McDowall M, Feil D, Robker R, Thompson J, Dunning K. Utilization of endogenous fatty acid stores for energy production in bovine preimplantation embryos. Theriogenology. 2012;77(8):1632-41.

Recebido em:

Aceito em:

Mendez Y, Parra N, Baez F, Valeis R, Villamediana P. Lipid content, mitochondrial activity and early embryo development in oocyte collected from crossbred cows (Bos taurus indicus). Vet. e Zootec. 2018 mar.; 25(1): 120-131. 